\title{
HOW TO DRIVE BRAND ENGAGEMENT AND EWOM INTENTION IN SOCIAL COMMERCE:A COMPETITIVE STRATEGY FOR THE EMERGING MARKET
}

\author{
- Quyen Phu Thi Phan, Nhat Tan Pham, Lien H.L Nguyen
}

\begin{abstract}
Brand engagement and eWOM intention have been found to be critical factors driving competitive advantage for companies, as the evolution of social networking sites has changed the perspective of how companies engage with customers. Based on social exchange theory, the current research proposes an empirical model that emphasizes (1) the unique role of social commerce characteristics, including personalization, socialization, and information availability, in enhancing consumer-brand engagement, (2) the connection between consumer-brand engagement and eWOM intention, and (3) the moderating influence of trust towards such connection. A survey of 248 Facebook users with online shopping experience was employed. By using PLS-graph 3.0, structural equation modelling, the findings demonstrate that personalization and socialization positively influence brand engagement, which in turn leads to eWOM intention. Furthermore, trust moderates the brand engagement-eWOM intention relationship. Unexpectedly, information availability has shown no significant effect on brand engagement. The study encompasses the knowledge of social exchange theory into the social commerce environment by investigating the linkage between the social commerce environment and brand engagement. It contributes value to marketing theories by describing the moderating role of trust from the viewpoint of Gen Y. In addition, the study's findings may shed light on how firms in emerging markets can increase competitiveness by stimulating brand engagement and eWOM intention, as well as enhancing consumer trust in the comments regarding the products/services within the social commerce environment.
\end{abstract}

Keywords: social exchange theory, social commerce characteristics, brand engagement, eWOM intention, trust, competitiveness

JEL Classification: M31

Received: October, 2019

1st Revision: April, 2020

Accepted: June, 2020 


\section{INTRODUCTION}

Social media has transformed the role of customers into active transaction users by empowering them to engage in value co-creation (Sorensen et al., 2017). Knowledge regarding engagement has helped companies better understand customer needs and thus provides feedback on strategies and product development. Moreover, social media can enable companies to build a longterm relationship and enhance their competitiveness in the context of Industry 4.0 (Ungerman et al., 2018; Van Doorn et al., 2010). Nevertheless, many firms fear financial and value loss for both themselves and consumers because of the challenges connected with fostering an engaging environment (Gong, 2018). A significant challenge for managers is to explore how social media transfers value to empowered customers. As a result, it is necessary for companies to gain a deeper understanding of how to drive consumer participation in the brand on social networking sites.

Social networking sites, e.g., Facebook, have long been recognized as a key marketing channel to drive engagement and brand awareness (Tsai et al., 2017). Consumers can interact with brands in a direct way by following the Facebook page of the brand, including posts on the page. One brand post can attract thousands of followers to interact with the brand as well as with other commenters. Despite this trend, studies examining the impetus for consumer engagement have been limited, with much more research needed to be done in this area (Roy et al., 2018). Hriganar et al. (2017) has argued that since customer engagement is facilitated by the social commerce environment, a broader view must be taken as to how particular social commerce characteristics influence on-line consumer brand engagement. Barger et al. (2016) has suggested that future research explore the role of consumer engagement in social media. Responding to this call, the present study examines the influence of social commerce features on consumer brand engagement.

Social commerce provides significant benefits to both customers and retailers. Piller et al. (2012) has indicated that social media may lead consumers to potential benefits of the product or service that they had been unaware of. These discussions are linked with the cost-effectiveness perspectives of social exchange theory, which the current study draws on to explore the relative impacts of benefits of the social commerce environment.

Furthermore, eWOM is placed as a consequence of brand engagement in this study. The term eWOM has attracted much attention from researchers. Several factors have been identified as determinants of eWOM intentions, for example, customer value (Kim et al., 2015), trust (Phan \& Pilik, 2018), and customer satisfaction (Yang, 2017). However, the emergent impact of the social commerce context on eWOM has also not been neglected (Zhang et al., 2014). Furthermore, Verhoef et al. (2010) has considered engagement as a trait manifestation of behavior. The researchers have identified a variety of similar characteristics to behaviors such as word-of-mouth, arguing that brand engagement has the potential to identify several related behaviors. Therefore, this study adds to the existing research by investigating the effect of brand engagement on user intention in eWOM via social media which can enhance the competitive advantages for companies.

Furthermore, trust is a key factor in influencing individual behaviors toward social media platforms (Nadeem et al., 2017). Trust is a complicated factor that appears to influence multiple facets of the individual's attitudes and behaviors. Alsaad et al. (2017) have highlighted that trust 
plays a moderating role in the online environment, where the motives for behaviors have not been well explained. On the other hand, prior studies have called for further research investigating the impact of moderating factors in brand engagement context (Alsaad et al., 2017; SeeTo \& Ho, 2014). To the authors' knowledge, there has only been one study that has tested the moderating effect of trust in the linkage of engagement and brand equity (Chahal \& Rani, 2017). Therefore, the current study breaks new ground in examining the moderating role of trust in the association between brand engagement and eWOM intention.

Also of interest are findings suggesting that the potential of social media in emerging markets is greater than that of developed countries due to the later growth of internet penetration as well as the resultant impact on consumer lifestyle changes. The world seems to be witnessing a change in how sellers and buyers interact in emerging markets (Gibreel et al., 2018). Arikan (2017) has declared that a gap remains in the literature on online brand engagement in the emerging market context, but this research will not be valuable if the parameters and assumptions applied in studies of the developed market are rigorously applied to emerging markets. Keeping this in mind, we selected the Southeast Asia region because it has the most daily-active users worldwide (Leeraphong \& Papasratorn, 2018). Approximately $30 \%$ of online sales take place via social media in Southeast Asia (Hoppe et al., 2016). More specifically, we tested the conceptual model in Vietnam context, which is ranked seventh among the countries with the highest number of Facebook users, showing the largest rapid growth in Southeast Asia (Tung, 2017). Over 70\% of Vietnamese customers have purchased products or services on the Facebook platform (Dat Nguyen, 2019).

Consequently, the main purpose of this study is to explore the antecedents and consequences of brand engagement towards social commerce characteristics and eWOM intention by proposing and empirically testing (1) the direct effects of personalization, socialization, and information availability on consumer-brand engagement, (2) the impact of this engagement on eWOM intention, and (3) trust as a moderating factor affecting the relationship between brand engagement and eWOM intention. The study focuses on consumer behavioral intentions in the emerging market.

Our research seeks to make key contributions to the social commerce literature as follows. First, the paper contributes to existing theories by addressing an unexplored area, i.e. the process that forms potential user engagement toward a brand, and user intentions to spread positive word of mouth in social commerce through social exchange theory. Second, our study ranks among the early empirical endeavors testing the engagement effect on eWOM intention using trust as a moderator. Third, the proposed model is applied to emerging markets (Vietnam) in which social commerce features may differ from previous outcomes in Western countries (Mikalef et al., 2017). Thus, the testing of customer engagement in emerging markets meets pressing needs and seeks to address serious gaps in the literature. Finally, the study can provide insights into the effects of social commerce characteristics and brand engagement, which in turn can help firms create, sustain and improve relative competitiveness. 


\section{THEORETICAL BACKGROUND}

\subsection{Definitions of Constructs}

\section{Social Commerce Characteristics}

Social commerce is viewed as "an important/crucial platform in e-commerce, primarily due to the increased popularity of social networking sites, such as Facebook, LinkedIn and Twitter" (Liang et al., 2011). Another definition of social commerce introduced by Gibreel et al. (2018) refers that "social e-commerce is e-commerce that is enabled by social networks and on-line social relationships. It is sometimes referred to as Facebook commerce, however, social commerce is a much larger phenomenon beyond Facebook."

To identify the characteristics of the social commerce environment, most studies used the motivation theory. They argued that the process of shopping is considered to be a sequence of behaviors, together with motivation in influencing their shopping behavior. Mikalef et al. (2013) explored social commerce characteristics based on the utilitarian and hedonic motivation theory. In particular, utilitarian motivations contain convenience, available information, a variety of products, personalized advertisement, while hedonic motivations include trend discovery, adventure, and authority. Based on both motivation and User-Generated Content theory, Mikalef et al. (2017) drew four constructs, namely socialization, personalized recommendation, information availability, and product selection. Zhang et al. (2014) discussed social commerce constructs through three factors: perceived socialization, perceived personalization, and perceived interactivity. A literature review of Zhang \& Benyoucef (2016) classified the social commerce platform into three main constructs, such as content, interaction, and network. In particular, the content characteristic includes information and entertainment, interaction characteristics include interactivity and socializing, and network characteristics include homophile and tie strength. Despite many reviewed factors in the social commerce environment, information availability, personalization, and socialization are the most frequently discussed features of using Internet and social networking sites. Therefore, this study suggests that information availability, socialization, and personalization are the main features of the social commerce environment.

Following the conceptions of socialization, personalization, and information availability in the previous studies (Mikalef et al., 2013; Mikalef et al., 2017; Zhang et al., 2014), we define socialization as the degree to participate in the interaction among consumers when using social media platforms to browse products/services. Personalization is the degree to provide consumers with a customized advertisement based on their needs. Information availability is the quantity of available product/service information on social commerce platforms, such as detailed descriptions of the product, special offerings, or promotions.

\section{Brand Engagement}

Brand engagement is defined as "the extent to which consumers are willing to invest their own personal resources - time, energy, money - in the brand, beyond those resources expended during purchase or consumption of the brand" Keller (2013). The border definition is "a psychological state that occurs virtue of interactive, co-creative customer experience with a focal agent/ object (e.g., a brand) in focal service relationships." (Brodie et al., 2011). Consumer engagement 
is either a uni-dimensional or a multiple-dimensional concept. For instance, Campell et al. (2014) measured brand engagement as a behavioral component that focuses greatly on how customers engaged with a brand/ companies on social media platform. Brodie et al. (2011) suggested three dimensions of customer engagement, including cognitive, affective and behavioral engagement. However, the current study aims to adopt the existing studies on brand engagement that used the uni-dimensional construct of consumer engagement, which is described as the degree to which customers participate in brands/companies on the Facebook platform, beyond purchasing, resulting from motivational factors.

\section{eWOM Intention}

eWOM is described as "any positive or negative statement made by potential, actual, or former customers about a product or company, which is made available to a multitude of people and institutions via the Internet" (Hennig-Thurau et al., 2004). Although eWOM includes positive and negative words, managers prefer positive comments. The positive eWOM helps companies marketing products/services without any advertisement cost (Lien \& Cao, 2014). Additionally, the study proposed eWOM intention instead of actual eWOM behavior because it is argued that the behavior is mostly dependent on the intention to respond to the behavior (Ajzen, 1977). Therefore, the positive eWOM intention means that consumers intend to spread positive words about the brand on social networking sites.

\subsection{Hypotheses Development}

\section{The Effects of Social Commerce Environment on Brand Engagement}

According to social exchange theory (Blau, 1968), when an individual receives benefits from others, they tend to interchange by giving to others. Consumers tend to consider the benefits and costs to decide whether or not to engage in brand pages (Zheng et al., 2015). Users' engagement is positively defined by their perceptions of the benefit. Following this line to social commerce, we argue that social commerce characteristics, namely, socialization, personalization, and information availability bring benefits to promote consumers' engagement toward the brand.

Firstly, Mikalef et al. (2017) indicated that social interaction provided by social commerce platforms is usually the main reason for consumers to go shopping. Socializing does not have to be limited to face-to-face communication in a traditional store but interaction via chat room, forums, or on-line discussions. Social interaction is inherent in hedonic benefits during shopping. During social interaction, consumers are gratified and they feel that they are valued by others. Jahn et al. (2012) stated that a customer may derive social-interaction benefits where they communicate, discuss and contact with individuals. Social interaction with others leads to knowledge exchange and, therefore, promoting brand engagement. Drawing on the social exchange theory, customers reciprocated with the company when they get benefits, where they develop an increased likelihood to show customer engagement in the brand (Carlson et al., 2018). In the current study, we argue that socialization characteristic of the social commerce environment is suggested to increase consumer engagement in the brand. Therefore, it is predicted that:

H1: Socialization has a positive effect on brand engagement. 
Personalization characteristic of the social commerce environment focuses mainly on providing consumers with personal content based on their needs, preferences, profile, historical actions forming a social network relationship (Zhang et al., 2014). In this context, consumers receive benefits from personalized communication and offerings based on the consumers' individual needs. Additionally, personal recommendation is posited to reduce consumers' information screening costs (Kang et al., 2016). Adopting the social exchange theory perspective, interpersonal behavior is explained by the costs and benefits of individuals (Ajzen, 1977). In that sense, the personalization feature contributes to a sense of benefits and costs of a potential consumer, and as a result, drives their brand engagement behavior.

On the other hand, the social exchange theory states that individuals will engage with a brand if they are in-turn receive benefits from that brand (Harrigan et al., 2018). For the brand and customer relations to persist, a customer must maintain a balance between expenses and benefits over time. The personalization factor makes an individual feel more important and valued. The degree to which consumers satisfy specific individual needs to be consistent with their linking is a good and rational way to propose that social commerce provides help for them and bring values to them (Zhang et al., 2014). Consumers thus have a positive attitude to participate in brand communities. Consequently, we can hypothesize that:

H2: Personalization is positively related to brand engagement.

Consumers want to obtain information about the products/services available, and related selling/ buying activities during their shopping process (Luarn et al., 2015). According to De Vries \& Carlson (2014), if a brand post includes information such as product descriptions or an updated new trend of products, users are more likely to interact and purchase. If consumers are motivated, they are stimulated to reply to posts. Claffey \& Brady (2014) argued that the level of customer participation depends on the knowledge sharing with companies and other customers. Information availability generates knowledge for consumers, which promotes their brand knowledge awareness and then encourages their interaction with the brand. Additionally, information related to promotions, coupon or special offers may be directly and indirectly connected with benefits (Luarn et al., 2015). Consumers, thus, may actively engage in various brand-related activities to meet their personal needs. Information availability relates to the utilitarian benefits of consumers. Chahal \& Rani (2017) discussed that brand engagement prompt customers to gratify their utilitarian needs. Together with this, Rohm et al. (2013) stated that product/service information makes customers' interaction and engagement with brands on social media. Therefore, we hypothesize that:

H3: Information availability is positively related to brand engagement.

\section{The Effects of Brand Engagement and eWOM Intention}

Brand engagement is considered to be a behavioral motivator that elicits brand-related outcomes like behavioral intention (Vivek et al., 2012). Cheung et al. (2011) indicated that customer participation in the brand community will have a greater tendency to spread positive word of mouth about it. When engaging in a certain brand in an online setting, customers tend to provide their feedback and share their experience with others. According to Gavurova et al. (2018), consumers are willing to recommend the brand to others when they have good branding experience with 
brand communities on social media platforms. Customers like to generate positive words and introduce the brand to others if they have good experience. Hriganar et al. (2017) explored that a consumer is more likely to give positive words about a brand or to suggest a brand to others as an outcome of customer engagement. Therefore, we hypothesize that:

H4: Brand engagement has a positive influence on eWOM intention.

\section{The Moderating Role of Trust}

Online is a psychological state in which consumers may be vulnerable based on a particular positive change in the vendor's expectations. Trust occurs on three levels, such as interpersonal level, inter-organizational level, and system level. The current study concentrates on the degree of trust between consumers and social media platforms (inter-organizational level) and investigates whether consumers believe the review of the products/ services provided on this platform. Trust is the heart of interaction, such as information exchange, which involves a substantial amount of time and effort, and happens by linking customers with similar preferences, and hobbies (Kang et al., 2016). An absence of trust among the partners decreases the probability that consumers will share information with others. When a consumer spends his/her time and effort to engage in the brand community, trust is critical to facilitating relationships exchange, for example, spreading his/her positive experience with others (Bruhn et al., 2014). Chahal \& Rani (2017) argued that the lack of consumers' trust restricts customers from engaging with their brands, which in turn tends to decrease word-of mouth intention. Trust is described as a contextual and conditional factor that plays a moderating role rather than one having a direct effect (See-To \& Ho, 2014). Following this, Chahal \& Rani (2017) indicated that the context of engagement behavior should be influenced by moderating variables. In the context of this study, it is proposed that when customers perceive greater degree of trust, those who are willing to engage in a certain brand will have stronger intentions to generate positive word of mouth. Therefore, it is predicted that:

H5: Trust moderates the relationship between brand engagement and eWOM intention.

\section{RESEARCH OBJECTIVE, METHODOLOGY AND DATA}

\subsection{Data Collection}

The target respondent is Generation Y, aged 18 to 35 years old, who uses social networks on a regular basis, and Facebook, in particular (Nadeem et al., 2017). This age cohort represents individuals who exhibited the largest level of Facebook usage in Vietnam in 2018 (Hootsuite, 2018). Nadeem et al. (2017) also stressed that practitioners and scholars should examine Gen Y's social media usage because it may be a harbinger of the way people will behave in the future. To diverse respondents' profiles, three biggest cities in Vietnam (i. e., Ha Noi, Sai Gon, and Da Nang) were specifically selected because the majority of students and employees across the country are living in these cities. The respondents in our sample all had an active Facebook account and had shopping experience via Facebook at least once.

This research is conducted in Vietnam; the original English questionnaire was translated into Vietnamese first, and then was converted back into English again. Two academic experts were 
asked to check the consistency between the Vietnamese and the original English version. Before initiating the data collection, we employed a pilot test among 80 respondents in order to ensure the instrument's content validity. After the pilot test, the questionnaire was modified and then conducted to an online survey with the final version. This study focused on convenience sampling. The survey period spanned was two weeks, during which 248 responses were collected.

\subsection{Descriptive Statistics}

The sample comprised of 176 (71\%) female and 72 (29\%) male respondents, aged 18-35 years old. The data presents that a higher 90 percent of the respondents use Facebook daily. The top three most popular items are fashion (84.27\%), cosmetics (58\%), and food (56.45\%).

Tab. 1 - Descriptive Statistics. Source: own research

\begin{tabular}{|c|c|c|c|}
\hline \multicolumn{2}{|l|}{ Demographic Variables } & $\begin{array}{l}\text { Frequency } \\
(\mathrm{n}=248)\end{array}$ & $(\%)$ \\
\hline \multirow{2}{*}{ Gender } & Male & 72 & 29 \\
\hline & Female & 176 & 71 \\
\hline \multirow{3}{*}{ Age } & Age $18-24$ years old & 76 & 30.6 \\
\hline & Age 25- 29 years old & 110 & 44.4 \\
\hline & Age $30-35$ years old & 62 & 25 \\
\hline \multirow{6}{*}{ Occupation } & Worker & 84 & 33.9 \\
\hline & Business & 25 & 10.1 \\
\hline & Household & 4 & 1.6 \\
\hline & Employee & 54 & 21.8 \\
\hline & Student & 69 & 27.8 \\
\hline & Others & 12 & 4.8 \\
\hline \multirow{4}{*}{ Frequency purchasing on Facebook } & $<=1$ time per week & 23 & 9.3 \\
\hline & Several times per week & 18 & 7.3 \\
\hline & $<=1$ time per month & 116 & 46.8 \\
\hline & Several times per month & 91 & 36.7 \\
\hline \multirow{4}{*}{ Facebook usage frequency } & $<=1$ time/day & 13 & 5.2 \\
\hline & Many time/ day & 227 & 91.5 \\
\hline & $<=1$ time/ week & 1 & 0.4 \\
\hline & Several times/ week & 7 & 2.8 \\
\hline \multirow{6}{*}{$\begin{array}{l}\text { Which products you often purchase on } \\
\text { Facebook }\end{array}$} & Fashion & 209 & 84.27 \\
\hline & Cosmetics & 144 & 58.06 \\
\hline & Electronics & 76 & 30.64 \\
\hline & Travel & 32 & 12.9 \\
\hline & Food & 140 & 56.45 \\
\hline & Others & 16 & 6.4 \\
\hline
\end{tabular}




\subsection{Measurements}

There were three constructs of interest. The three dimensions of social commerce environment (e.g., information availability, personalization, socialization) are modified by Mikalef et al. (2017), and Zhang et al. (2014). The measurement of brand engagement originally adopts of Campbell et al. (2014). To study this phenomenon in a general sense that is not limited to engagement in a specific brand, the respondents were explicitly asked about brands that they had liked or followed. The respondents were informed about various brands' Facebook pages and asked to report on the brands' Facebook pages that they had followed or commented in past 15 days prior to completing the survey. The items of positive eWOM are adjusted from Lien \& Cao (2014). The seven-point Likert scale ranging from "strongly disagree $=1$ " to "strongly agree $=7$ " is used in this study.

\section{Common Method Bias}

In order to reduce non-response bias during the data collection, this study made the following steps according to Podsakoff et al. (2003). Firstly, a set of pre-tests was used to ensure the clarity of the measurement. Second, the study performed the Harman's single factor test. The explained variance of a single factor was $43.44 \%$, lower than the rule of thumb of $50 \%$. Third, all of the factor loadings were higher than the threshold of 0.7. To sum up, common method bias does not happen in this study.

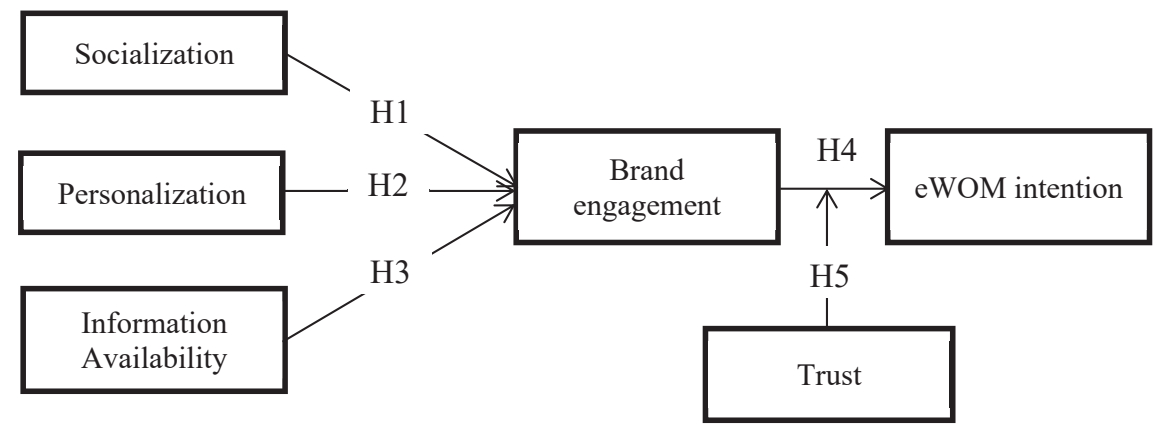

Fig. 1 - The conceptual model. Source: own research

\section{RESULTS AND DISCUSSION}

\subsection{Measurement Model}

The measurement validity and reliability were carried out as follows: the factor loading and Cronbach's $\alpha$ are greater than the desired threshold of 0.7 . The composite reliability values are also higher than the value recommended in the literature (Hair et al., 2014). In addition, the AVE values of all the constructs exceed 0.5 (Hair et al., 2014), suggesting adequate convergence. Table 2 revealed a reasonable internal consistency reliability. 
The discriminant validity in PLS (Henseler et al., 2015) was tested in two ways, such as the Fornell-Larcker criterion (Fornell \& Larcker, 1981) and the heterotrait-monotrait ratio of correlations (HTMT). The resulting data in Table 3 indicated that the discriminant validity met the threshold.

Tab. 2 - The outcomes of confirmatory factor analysis. Source: own research

\begin{tabular}{|c|c|c|}
\hline Items & & Loadings \\
\hline \multicolumn{3}{|c|}{$\begin{array}{l}\text { Social commerce characteristics Socialization } \\
\text { (Cronbach's } \alpha=.757, \mathrm{CR}=.861, \mathrm{AVE}=.674)\end{array}$} \\
\hline 1 & SC1 & 0.818 \\
\hline 2 & SC2 & 0.869 \\
\hline 3 & SC3 & 0.772 \\
\hline \multicolumn{3}{|c|}{$\begin{array}{l}\text { Personalization } \\
(\text { Cronbach's } \alpha=.77, \mathrm{CR}=.865, \mathrm{AVE}=.681)\end{array}$} \\
\hline 1 & PER1 & 0.808 \\
\hline 2 & PER2 & 0.838 \\
\hline 3 & PER3 & 0.829 \\
\hline \multicolumn{3}{|c|}{$\begin{array}{l}\text { Information Availability } \\
(\text { Cronbach's } \alpha=.794, \mathrm{CR}=.880 ; \text { AVE }=.711)\end{array}$} \\
\hline 1 & INF1 & 0.861 \\
\hline 2 & INF2 & 0.914 \\
\hline 3 & INF3 & 0.744 \\
\hline \multicolumn{3}{|c|}{$\begin{array}{l}\text { Brand engagement } \\
(\text { Cronbach's } \alpha=.893, \mathrm{CR}=.906, \mathrm{AVE}=.617)\end{array}$} \\
\hline 1 & BE1 & 0.758 \\
\hline 2 & BE2 & 0.813 \\
\hline 3 & BE3 & 0.817 \\
\hline 4 & $\mathrm{BE} 4$ & 0.727 \\
\hline 5 & BE5 & 0.812 \\
\hline 6 & BE6 & 0.781 \\
\hline 7 & BE7 & \\
\hline \multicolumn{3}{|c|}{$\begin{array}{l}\text { eWOM intention } \\
(\text { Cronbach's } \alpha=.83, \mathrm{CR}=.898, \mathrm{AVE}=.745)\end{array}$} \\
\hline 1 & eWOM1 & 0.841 \\
\hline 2 & eWOM2 & 0.870 \\
\hline 3 & eWOM3 & 0.878 \\
\hline
\end{tabular}


Tab. 3 - The assessment of discriminant validity. Source: own research

\begin{tabular}{|l|l|l|l|l|l|}
\hline Constructs & INF & BE & EW & PER & SC \\
\hline Information (INF) & 0.843 & 0.467 & 0.568 & 0.697 & 0.787 \\
\hline Brand engagement (BE) & 0.398 & 0.780 & 0.732 & 0.619 & 0.593 \\
\hline eWOM intention (EW) & 0.469 & 0.636 & 0.864 & 0.668 & 0.605 \\
\hline Personalization (PER) & 0.539 & 0.527 & 0.541 & 0.825 & 0.585 \\
\hline Socialization (SC) & 0.606 & 0.489 & 0.477 & 0.451 & 0.821 \\
\hline $\begin{array}{l}\text { Note: Heterotrait-Montrait Ratio (HTMT) above the diagonal; square root of the AVE } \\
\text { (bold), and correlations between dimensions under the diagonal (Fornell - Larcker criterion) }\end{array}$
\end{tabular}

\subsection{The Evaluation of the Structural Model}

Before analyzing the structure model, collinearity problem was examined through the Variance inflation factor (VIF) generated by SPSS 22 version. The results of VIF show the value of 1.609 for socialization, 1.443 for personalization, and 1.825 for information availability. All the values were lower than the benchmark value 3 (Hair et al., 2014). Thus, multi-collinearity is not a matter in the current study.

The first hypothesis predicting that socialization would positively affect brand engagement is supported H1 $(\beta=0.316, p<0.001)$. Likewise, personalization has a positive effect on brand engagement, supporting $\mathrm{H} 2(\beta=0.386, \mathrm{p}<0.001)$. However, the findings reject $\mathrm{H} 3(\beta=-0.002$, $\mathrm{p}=0.982)$. Finally, regarding the relationship between brand engagement and eWOM intention, our findings support the favorable effect of brand engagement on eWOM intention, supporting H4 ( $\beta=0.636, \mathrm{p}<0.001)$ (see Table 4).

Additionally, the coefficient of determination $\left(\mathrm{R}^{2}\right)$ for brand engagement was 0.357 , and $\mathrm{R}^{2}$ for eWOM intention was 0.405 . Each surpassing the threshold of 0.3 implies that these is a high influence of the antecedents of social commerce on brand engagement, having an effect on eWOM intention.

Tab. 4 - The structural model results. Source: own research

\begin{tabular}{|l|l|l|l|}
\hline Hypo. & Path & $\begin{array}{l}\text { Standardized path } \\
\text { coefficients }\end{array}$ & t-value \\
\hline H1 & Socialization $\rightarrow$ Brand engagement & $0.316^{* * *}$ & 2.783 \\
\hline H2 & Personalization $\rightarrow$ Brand engagement & $0.386^{* * *}$ & 3.539 \\
\hline H3 & Information $\rightarrow$ Brand engagement & $-0.002 \mathrm{~ns}$ & 0.014 \\
\hline H4 & Brand engagement $\rightarrow$ eWOM intention & $0.636^{* * *}$ & 8.65 \\
\hline
\end{tabular}

\subsection{The Mediation Role of Brand Engagement}

This study has made a further step in investigating the mediating role of brand engagement in perceptions between personalization, socialization, and eWOM intention. Generally, the relationship of the independent variable $\mathrm{X}$ and the dependent variable $\mathrm{Y}$ is mediated by a third variable, $\mathrm{M}$, called the mediator. In this study, $\mathrm{X} 1$ is a socialization feature, $\mathrm{X} 2$ is a personaliza- 
tion feature, M is brand engagement, and Y is eWOM intention. Following Hair et al.' s (2017) guidelines, the simple mediator model is developed, whereby $\mathrm{p} 3$ is the direct effect, $\mathrm{p} 1 . \mathrm{p} 2$ is the indirect effect, and the direct effect (p3) + the indirect effect (p1.p2) = the total effect (Figure 2).

There are two main steps to test the mediating effect. Firstly, the indirect effect p1.p2 must be significant to establish a mediation effect. The second step discusses the type of mediation, full or partial mediation.

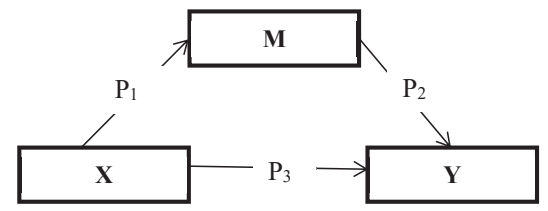

Fig. 2 - Testing the mediating procedure. Source: own research

Using this procedure, we evaluate the indirect effect p1.p2 of socialization (X1) on eWOM intention $(\mathrm{Y})$ was significant ( $\mathrm{p}$-value $<0.001)$. The finding confirmed that there always exists a mediating effect. Then, the direct effect (p3) was also significant ( $\mathrm{p}$-value $=0.024)$. We concluded that there is a partial mediating effect of brand engagement on the connection between socialization and eWOM intention.

Following the same procedure, we examined whether brand engagement mediated the relationship between personalization and eWOM intention. Supporting this statement, both the estimates of the indirect effect (p1.p2) and direct effect (p3) were positive and significant (p-value= 0.001 and 0.001 , respectively). As a consequence, the effect of personalization on eWOM intention is partially mediated through brand engagement.

\subsection{The Moderating Role of Trust}

The study used K-means cluster analysis in SPSS version 20. Specifically, we divided the data into four groups using brand engagement and the moderators $(2 \times 2)$ as the clustering variables, including High BE/Low Trust, High BE/High Trust, Low BE/ Low Trust, Low BE/ High Trust. The findings showed that consumers with high trust tended to have a stronger eWOM intention $(\mathrm{F}=$ 41.521, $\mathrm{p}=0.000$ ) when engaging in the brand (Figure 3). Thus, the findings indicated trust as a moderator in the brand engagement and eWOM intention relationship. The H5 hypothesis is supported.

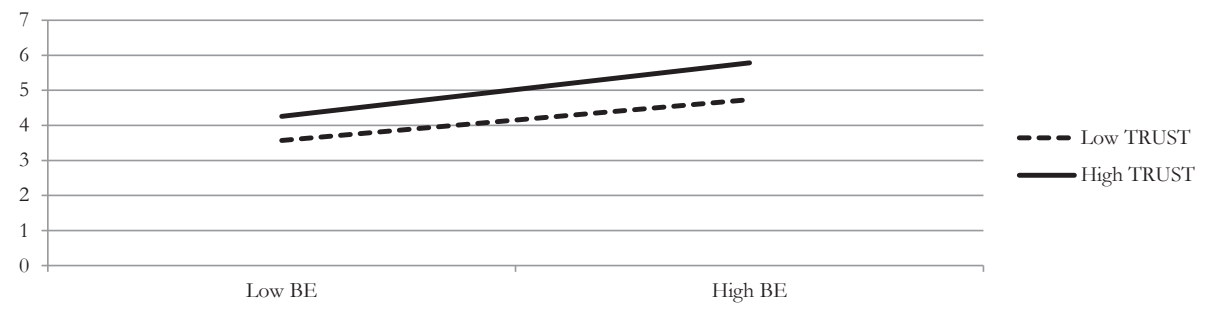

Fig. 3 - The effect of a trust moderator. Source: own research 


\subsection{Discussion}

To maintain competitive advantages, companies need to attract and keep new customers. The development of social media has changed how companies interact and communicate with customers. Companies must use social networking sites as an alternative strategy to engage customers and generate positive word of mouth to reach and stabilize competitive advantage. Prior studies have stressed customer engagement as an effective approach for developing and maintaining customer relationships (Luarn et al., 2015; Kang et al., 2016). Determining and perfecting ways in which companies can design social commerce features to enhance brand engagement among their customers is a critical issue in the emerging e-retailing market.

The outcome of this research has identified two salient characteristics of the social commerce environment and its relation to brand engagement: socialization and personalization. Socialization features help users reach a diverse group of people. Consumers can gather and give information or express their experiences. They can enjoy the interaction and communication with others. This exchange process brings benefits to consumers and leads them to engage in the brand community. Additionally, the feature of personalization helps companies accurately identify customer needs and interests, thus enhancing consumer brand engagement. This feature can bring value for customers, as the time and cost of searching for information decreases, while consumers gain a product fit. This finding is consistent with a study of Chahal \& Rani (2017) which showed that personalized advertisements lead to a more positive attitude in terms of consumer engagement in a social media context. In contrast, information availability does not influence brand engagement. This non-significant finding may be due to the volume of information and its structure or the lack of information. Mikalef et al. (2017) also found that available information had no influence on purchase intention and eWOM intention. Information overload can cause a barrier to prevent consumers from taking the next step toward a brand.

The study provides empirical support to the underlying influence that brand engagement plays a critical role in driving customer intention in terms of positive word of mouth in the Facebook commerce environment. More importantly, in contrast to the study of Mikalef et al. (2017) which focused on how social commerce characteristics effect eWOM intention, this research explores the mediating role of brand engagement in this relationship. In this context, to gain a better understanding of the concept and its potential uses it seems more advantageous to study how brand engagement acts as a mediator step than studying it in terms of eWOM.

Additionally, this study concurs with a previous study that confirmed that an understanding of consumer trust can help encourage consumer engagement in the social commerce environment (Chahal \& Rani, 2017). That is, the relationship between brand engagement and eWOM intention is influenced by the level of trust users have in the comments of products/services read on the Facebook platform. We concluded that the greater the degree of consumer trust about the comments on products/services on social media, the more likely consumers are to engage with the brand and subsequently spread their positive experiences by word of mouth. 


\section{CONCLUSION}

\subsection{Theoretical and Practical Implications}

This study provides a new theoretical perspective of a company's competitiveness through enhancing brand engagement and generating eWOM in the social commerce environment. Social exchange theory offers a theoretical background for explaining the positive effect of social commerce characteristics on brand engagement. It is clear that the benefits of social commerce platforms lie in the motivation of consumers to interact and engage with the brand. These findings contribute to the literature by adding new insights into the growing research into the role of social commerce and related customer-centered design. We also validate and revise three salient characteristics of the social commerce environment from previous studies in the Facebook commerce context. The specific focus on Facebook commerce is a critical contribution that adds weight to literature on Facebook marketing (Nadeem et al., 2017). Our findings have identified the effects of two salient characteristics of social commerce platform (e.g., socialization, personalization) on brand engagement. In addition, we name eWOM intention as a consequence of brand engagement. This outcome additionally contributes to the existing literature showing that consumers who invest more time and resources in the brand will tend to have higher intentions of spreading positive words to others. Alsaad et al. (2017) has suggested that future research should examine the impact of various moderators in brand engagement. The current study fills a knowledge gap in the marketing literature by presenting empirical evidence regarding consumer trust in terms of the comments of products/ service posted on social media platforms, which can in turn trigger changes in how consumer engagement in a certain brand influences their eWOM intention. Finally, the study contributes a rich source of knowledge of competitiveness issues in the emerging market from the perspective of Gen Y.

The study can enhance practical competitiveness strategies for online retailers in emerging markets. Firstly, the characteristics of social media are a great source of competitive advantage, as these provide value and benefit to engage consumers. Marketers might experiment with more effective ways to encourage peer communications among consumers who are less socially interacted to enhance their engagement with a particular brand. Furthermore, personalization characteristics of Facebook commerce have been found to increase consumer engagement in a brand. Results regarding this aspect stress user attention to particular content. Based on consumer preference and their recent online activities, marketers should focus effectively on key topics, encouraging user engagement related to services and applications they already like. Also, the availability of greater information regarding other customers may be impeded by the negative word of mouth of a neglected customer. In alleviating this negative feedback or avoiding it altogether, firms can secure or retain a competitive advantage, e.g. by providing price or quality comparisons with other brands to consumers in a cost-effective way. When consumers interact with products and services by following the brand Fan page, they can easily share or recommend them to other people with just one click. Finally, marketers can find an effective way of increasing consumer trust in the comments on products/services on the Facebook platform. The overall mean of trust is 3.91 (out of 7), indicating that the Vietnamese users believe only slightly in comments on products/services written on Facebook. A reason for that can be that Vietnamese Facebook users are more likely to be confident about comments posted by their friends rather than by 
unknown users. Following this trend, marketers can find ways to encourage their customers to write online reviews for their company. In addition, consumers tend to share negative comments more often rather than positive comments. Although the negative comments cause consumers to decrease their belief in the products/services, marketers should not completely remove negative feedback. It is a reality that if customers see only positive comments on a social media page, they are not going to believe it. Thus, even negative comments can help companies improve customer trust. This problem should be resolved by building a great customer service team that cares about what consumers say and that addresses each consumer's concerns quickly and in the right way. Further, past dissatisfied customers whose needs have now been met by the customer service team should subsequently be incentivized to post positive comments on the brand's social media page. The more attention a negative comment has received (e.g. in terms of likes), the greater the incentive should be offered for the user to now post a positive comment.

\subsection{Limitations and Suggestions for Future Research}

Like any other study, this study has several limitations which may also provide fertile grounds for further research. First, the key limitation is that it examines the conceptual model using the Facebook platform, thus the results may not be generalized to other platforms such as Instagram or Twitter. Second, this research surveyed Facebook users in Vietnam, and thus it may not be representative of the sum total of Facebook users in other countries. The respondents were also limited to Gen Y. The following study was meant to examine cross-cultural issues, i.e. like comparative studies from other developed and developing countries it seeks to be contributive to the overall knowledge of brand engagement within the social commerce environment. Meanwhile, it may be beneficial to examine the different kinds of social commerce platforms across a diversity of age and other demographic ranges. Third, brand engagement is stated as a multi-dimensional concept; thus, it would be valuable to access the validity scale of this concept. Finally, besides brand engagement and eWOM intention, there are many other important factors to consider in promoting a company's competitiveness in social commerce platforms which should be considered in the future studies, e.g. customer experience and value co-creation.

Acknowledgements

The research for this article was financially supported by the Internal Grant Agency of the Faculty of Management and Economics, Tomas Bata University in Zlín, grant No. IGA/FaME/2018/015.

\section{References}

1. Ajzen, I. C. E. K. (1977). Information processing approaches to interpersonal attraction. Theory and practice in interpersonal attraction, 51-77.

2. Alsaad, A., Mohamad, R., \& Ismail, N. A. (2017). The moderating role of trust in business to business electronic commerce (B2B EC) adoption. Computers in Human Behavior, 68, 157-169. https://doi.org/10.1016/j.chb.2016.11.040

3. Arrkan, E. (2017). Engagement with online customers in emerging economies: The power of online brand communities and social networking sites. Promotional strategies and new service opportunities in emerging economies, 184-209. IGI Global. https://doi.org/10.4018/978-1-52252206-5.ch009royy 
4. Barger, V., Peltier, J. W., \& Schultz, D. E. (2016). Social media and consumer engagement: a review and research agenda. Journal of Research in Interactive Marketing, 10 (4), 268-287. https:// doi.org/10.1108/JRIM-06-2016-0065

5. Blau, P. M. (1968). Social exchange. International encyclopedia of the social sciences, 7, 452-457.

6. Brodie, R. J., Hollebeek, L. D., Jurić, B., \& Ilić, A. (2011). Customer engagement: Conceptual domain, fundamental propositions, and implications for research. Journal of service research, 14 (3), 252-271. https://doi.org/10.1177/1094670511411703

7. Bruhn, M., Schnebelen, S., \& Schäfer, D. (2014). Antecedents and consequences of the quality of e-customer-to-customer interactions in B2B brand communities. Industrial Marketing Management, 43 (1), 164-176. https://doi.org/10.1016/j.indmarman.2013.08.008

8. Campbell, C., Ferraro, C., \& Sands, S. (2014). Segmenting consumer reactions to social network marketing. European Journal of Marketing, 48 (3), 432-452.

9. Carlson, J., Rahman, M., Voola, R., \& De Vries, N. (2018). Customer engagement behaviour in social media: capturing innovation opportunities. Journal of Services Marketing, 32 (1), 83-94. https://doi.org/10.1108/JSM-02-2017-0059

10. Chahal, H., \& Rani, A. (2017). How trust moderates social media engagement and brand equity. Journal of Research in Interactive Marketing, 11 (3), 312-335. https://doi.org/10.1108/JRIM10-2016-0104

11. Cheung, C., Lee, M., \& Jin, X. (2011). Customer engagement in an online social platform: A conceptual model and scale development. ICIS 2011 Proceedings. 8. https://aisel.aisnet.org/ icis2011/proceedings/onlinecommunity/8

12. Claffey, E., \& Brady, M. (2014). A model of consumer engagement in a virtual customer environment. Journal of Customer Behaviour, 13 (4), 325-346. https://doi.org/10.1362/14753921 4X14185702584405

13. Dat Nguyen (2019). Facebook messenger most popular chat app for online shopping in Vietnam. https://e.vnexpress.net/news/business/data-speaks/facebook-messenger-mostpopular-chat-app-for-online-shopping-in-vietnam-3875405.html

14. De Vries, N. J., \& Carlson, J. (2014). Examining the drivers and brand performance implications of customer engagement with brands in the social media environment. Journal of Brand Management, 21 (6), 495-515. https://doi.org/10.1057/bm.2014.18

15. Fornell, C., \& Larcker, D. F. (1981). Structural equation models with unobservable variables and measurement error: Algebra and statistics.

16. Gavurova, B., Bacik, R., Fedorko, R., \& Nastisin, L. (2018). The customer's Brand experience in the light of selected performance indicators in the social media environment. Journal of Competitiveness, 10 (2), 72. https://doi.org/10.7441/joc.2018.02.05

17. Gibreel, O., AlOtaibi, D. A., \& Altmann, J. (2018). Social commerce development in emerging markets. Electronic Commerce Research and Applications, 27, 152-162. https://doi.org/10.1016/j. elerap.2017.12.008

18. Gong, T. (2018). Customer brand engagement behavior in online brand communities. Journal of Services Marketing, 2 (3), 286-299. 
19. Hair Jr, J. F., Sarstedt, M., Ringle, C. M., \& Gudergan, S. P. (2017). Advanced issues in partial least squares structural equation modeling. Sage Publications.

20. Hair Jr, J., Sarstedt, M., Hopkins, L., \& G. Kuppelwieser, V. (2014). Partial least squares structural equation modeling (PLS-SEM) An emerging tool in business research. European Business Review, 26 (2), 106-121. https://doi.org/10.1108/EBR-10-2013-0128

21. Harrigan, P., Evers, U., Miles, M. P., \& Daly, T. (2018). Customer engagement and the relationship between involvement, engagement, self-brand connection and brand usage intent. Journal of Business Research, 88, 388-396.

22. Hennig-Thurau, T., Gwinner, K. P., Walsh, G., \& Gremler, D. D. (2004). Electronic word-ofmouth via consumer-opinion platforms: what motivates consumers to articulate themselves on the internet?. Journal of interactive marketing, 18 (1), 38-52. https://doi.org/10.1002/dir.10073

23. Henseler, J., Ringle, C. M., \& Sarstedt, M. (2015). A new criterion for assessing discriminant validity in variance-based structural equation modeling. Journal of the academy of marketing science, 43 (1), 115-135. https://doi.org/10.1007/s11747-014-0403-8

24. Hootsuite. (2018). Digital 2018 in Vietnam. Essential insight into Internet, social media mobile, and Ecommerce use across the region. Retrieved from https://www.slideshare.net/ kiditer/vietnam-digital-landscape-2018.

25. Hoppe, F., Lamy, S., \& Cannarsi, A. (2016). Can Southeast Asia live up to its e-commerce potential. Bain \& Company, 16. https://www.bain.com/contentassets/f6880f16cbf648b28bdf6 9f772f6eca8/bain_brief_can_southeast_asia_live_up_to_ecommerce_potential.pdf

26. Hriganar, P., Evers, U., Miles, M., \& Daly, T. (2017). Customer engagement with tourism social media brands. Tourism Management, 59, 597-609. https://doi.org/10.1016/j. tourman.2016.09.015

27. Jahn, B., Kunz, W., \& Meyer, A. (2012). The role of social media for luxury brandsMotives for consumer engagement and opportunities for business. In Identitätsbasierte Luxusmarkenführung, 221-236. Springer Gabler, Wiesbaden. https://doi.org/10.1007/978-38349-4060-5_14

28. Kang, M., Shin, D. H. \& Gong, T. (2016). 'The role of personalization, engagement, and trust in online communities'. Information Technology and People, 29 (3), 580-596. https://doi. org/10.1108/ITP-01-2015-0023

29. Keller, K. L. (2013). Strategic brand management: building, measuring, and managing brand equity. 4th ed., global ed. Harlow: Pearson.

30. Kim, D., Jang, S., \& Adler, H. (2015). What drives café customers to spread eWOM? Examining self-relevant value, quality value, and opinion leadership. International Journal of Contemporary Hospitality Management, 27 (2), 261-282. https://doi.org/10.1108/ IJCHM-06-2013-0269

31. Leeraphong, A., \& Papasratorn, B. (2018). S-Commerce Transactions and Business Models in Southeast Asia: A Case Study in Thailand. KnE Social Sciences, 3 (1), 65. https://doi. org $/ 10.18502 / \mathrm{kss} . v 3 i 1.1397$

32. Liang, T. P., \& Turban, E. (2011). Introduction to the special issue social commerce: a research framework for social commerce. International Journal of electronic commerce, 16 (2), 5-14. 
33. Lien, C. H. \& Cao, Y. (2014). Examining WeChat users' motivations, trust, attitudes, and positive word-of-mouth: Evidence from China. Computers in Human Behavior, 41, 104-111. DOI: 10.1016/j.chb.2014.08.013

34. Luarn, P., Lin, Y. F., \& Chiu, Y. P. (2015). Influence of Facebook brand-page posts on online engagement. Online Information Review, 39 (4), 505-519. https://doi.org/10.1108/OIR-01-20150029

35. Mikalef, P., Giannakos, M. N., \& Pappas, I. O. (2017). Designing social commerce platforms based on consumers' intentions. Behaviour \& Information Technology, 36 (12), 1308-1327. https:// doi.org/10.1080/0144929X.2017.1386713

36. Mikalef, P., Giannakos, M., \& Pateli, A. (2013). Shopping and word-of-mouth intentions on social media. Journal of theoretical and applied electronic commerce research, 8 (1), 17-34. http://dx.doi. org/10.4067/S0718-18762013000100003

37. Nadeem, W., Juntunen, M., \& Juntunen, J. (2017). Consumer segments in social commerce: A latent class approach. Journal of Consumer Behaviour, 16 (3), 279-292. https://doi.org/10.1002/ cb.1632

38. Phan, Q. P. T., \& Pilík, M. (2018). The Relationship Between Website Design and Positive EWOM Intention: Testing Mediator and Moderator Effect. Journal of Business Economics and Management. https://doi.org/10.3846/jbem.18.5690

39. Piller, F. T., Vossen, A., \& Ihl, C. (2012). From social media to social product development: the impact of social media on co-creation of innovation. Die Unternehmung, 65 (1). https://ssrn. com/abstract $=1975523$

40. Podsakoff, P. M., MacKenzie, S. B., Lee, J. Y., \& Podsakoff, N. P. (2003). Common method biases in behavioral research: A critical review of the literature and recommended remedies. Journal of applied psychology, 88 (5), 879.

41. Rohm, A., D. Kaltcheva, V., \& R. Milne, G. (2013). A mixed-method approach to examining brand-consumer interactions driven by social media. Journal of Research in Interactive Marketing, 7 (4), 295-311. https://doi.org/10.1108/JRIM-01-2013-0009

42. Roy, S. K., Balaji, M. S., Soutar, G., Lassar, W. M., \& Roy, R. (2018). Customer engagement behavior in individualistic and collectivistic markets. Journal of Business Research, 86 (6), 281-290. https://doi.org/10.1016/j.jbusres.2017.06.001

43. See-To, E. W. K., \& Ho, K. K. W. (2014). Value co-creation and purchase intention in social network sites: The role of electronic Word-of-Mouth and trust - A theoretical analysis. Computers in Human Behavior, 31 (1), 182-189. https://doi.org/10.1016/j.chb.2013.10.013

44. Sorensen, A., Andrews, L., \& Drennan, J. (2017). Using social media posts as resources for engaging in value co-creation. Journal of Service Theory and Practice, 27(4), 898-922. https://doi. org/10.1108/JSTP-04-2016-0080

45. Stephen, A. T., \& Toubia, O. (2010). Deriving value from social commerce networks. Journal of marketing research, 47 (2), 215-228. https://doi.org/10.1509/jmkr.47.2.215

46. Tsai, W. H. S., \& Men, L. R. (2017). Consumer engagement with brands on social network sites: A cross-cultural comparison of China and the USA. Journal of Marketing Communications, 23 (1), 2-21. https://doi.org/10.1080/13527266.2014.942678 
47. Tung (2017). Vietnam has the highest e-commerce adoption rate in Southeast Asia: EIU Report. Retrieved from: https://e27.co/vietnam-most-online-shoppers-southeast-asiareport-20181105/

48. Ungerman, O., Dedkova, J., \& Gurinova, K. (2018). The impact of marketing innovation on the competitiveness of enterprises in the context of industry 4.0. Journal of Competitiveness, 10 (2), 132-148. https://doi.org/10.7441/joc.2018.02.09

49. Van Doorn, J., Lemon, K. N., Mittal, V., Nass, S., Pick, D., Pirner, P., \& Verhoef, P. C. (2010). Customer engagement behavior: Theoretical foundations and research directions. Journal of service research, 13 (3), 253-266. https://doi.org/10.1177/1094670510375599

50. Verhoef, P. C., Reinartz, W. J., \& Krafft, M. (2010). Customer engagement as a new perspective in customer management. Journal of service research, 13 (3), 247-252. https://doi. org $/ 10.1177 / 1094670510375461$

51. Vivek, S. D., Beatty, S. E., \& Morgan, R. M. (2012). Customer engagement: Exploring customer relationships beyond purchase. Journal of marketing theory and practice, 20 (2), 122-146. https://doi.org/10.2753/MTP1069-6679200201

52. Yang, F. X. (2017). Effects of Restaurant Satisfaction and Knowledge Sharing Motivation on eWOM Intentions: The Moderating Role of Technology Acceptance Factors. Journal of Hospitality and Tourism Research, 41 (1), 93-127. https://doi.org/10.1177/1096348013515918

53. Zhang, H., Lu, Y., Gupta, S., \& Zhao, L. (2014). What motivates customers to participate in social commerce? The impact of technological environments and virtual customer experiences. Information \& Management, 51 (8), 1017-1030. https://doi.org/10.1016/j. im.2014.07.005

54. Zhang, K. Z., \& Benyoucef, M. (2016). Consumer behavior in social commerce: A literature review. Decision Support Systems, 86, 95-108. https://doi.org/10.1016/j.dss.2016.04.001

55. Zheng, X., Cheung, C. M., Lee, M. K., \& Liang, L. (2015). Building brand loyalty through user engagement in online brand communities in social networking sites. Information Technology \& People, 28 (1), 90-106. https://doi.org/10.1108/ITP-08-2013-0144

\section{Contact information}

\section{Quyen Phu Thi Phan}

University of Economics, The University of Danang, Vietnam

Faculty of Marketing

Tomas Bata University in Zlin, Czech Republic

Faculty of Management and Economics

Vietnam

E-mail:t1phan@utb.č;phuquyen@due.edu.vn

ORCID: 0000-0002-4048-1369

\section{Nhat Tan Pham}

International University, Ho Chi Minh City, Vietnam

Vietnam National University, Ho Chi Minh City, Vietnam

Linh Trung Ward, Thu Duc District, Ho Chi Minh City 700000, Vietnam

Tomas Bata University in Zlin, Czech Republic 
Faculty of Management and Economics

Vietnam

E-mail:nhatpham1729@gmail.com

ORCID: 0000-0001-9927-2257

Lien H.L Nguyen

Tomas Bata University in Zlin, Czech Republic

Faculty of Management and Economics

Czech Republic

E-mail:Inguyen@utb.cz.

ORCID: 0000-0002-7527-6453 